\title{
Is Equity Finance, Macroeconomic Growth and Capital Intensity Relevant to Firm-Level R\&D Expenditures?
}

\author{
Jason Hecht ${ }^{1}$ \\ ${ }^{1}$ Anisfield School of Business, Ramapo College of New Jersey, Mahwah, New Jersey, USA \\ Correspondence: Jason Hecht, Anisfield School of Business, Ramapo College of New Jersey, Mahwah, New \\ Jersey 07430-1680, USA. E-mail: jhecht@ramapo.edu
}

Received: June 13, 2014

Accepted: June 23, 2014

Online Published: August 25, 2014

doi:10.5539/ijef.v6n9p11

URL: http://dx.doi.org/10.5539/ijef.v6n9p11

\begin{abstract}
This paper examines the association between firm-level research and development (R\&D) expenditures and net equity issuance, sales, gross cash flow, the capital to labor ratio, and the growth rate of inflation-adjusted (real) Gross Domestic Product (GDP) in a firm's home country. Dynamic panel models using General Methods of Moments techniques are estimated from an unbalanced sample of firms across the major industrialized economies as well as China and India from 1998 to 2008. Results from the full cross-country panel sample found a significant and positive association between R\&D expenditures and sales, net equity issuance and lagged real GDP; a negative association was found with the capital to labor ratio. Macroeconomic growth had a positive impact on R\&D expenses in each country but was statistically significant only for firms located in Germany, Great Britain, and the US. Equity capital is found to be a significant source of R\&D funding for US firms. However, estimates for non-US firms indicate that capital intensity nor net equity issuance was a consistently significant predictor of R\&D expenditures. The latter result may be due to cross-country differences in financial and institutional relationships between capital market and bank-based systems of corporate finance. Finally, this study underscores the importance of including macroeconomic growth in microeconometric panel models of R\&D investment.
\end{abstract}

Keywords: research and development expenditures, net equity issuance, capital labor ratio, macroeconomic growth, dynamic panel estimation

\section{Introduction}

Research and development (R\&D) expenditures typically play a critical role in increasing a firm's technical capabilities to invent, innovate, and create new products and services. The importance of R\&D investment to a firm's capital accumulation strategy was first emphasized by Schumpeter (1950) who believed that sustained technological advantage was critical for attaining competitive dominance. Schumpeter justified "monopoly practices" of large, vertically integrated businesses based on their need to finance risky R\&D expenditures out of accumulated earnings. Modern economic theory has long recognized that the payoffs from investments in research and development are both highly uncertain and involve significant costs for skilled personnel. Nelson (1959) and Arrow (1962) formally demonstrated how private markets would tend to under-invest in activities that generate new knowledge about production techniques due to the non-appropriability of their returns. While patent laws help to narrow the gap between private costs and benefits from R\&D expenditures, the underinvestment problem persists (Levin et al., 1987; Mansfield et al., 1981).

External financing for R\&D expenditures in the form of either bank loans or debt is thought to be problematic from a variety of theoretical and empirical perspectives. Unlike physical investments in plant, property, and equipment, R\&D expenditures consist largely of salaries for scientists and other specialized personnel. Thus, the inherent lack of collateral or tangible value usually restricts the use of debt finance. Secondly, R\&D investments rarely generate sufficient cash flows to pay initial or even intermediate-term debt service expenses. Thirdly, the need to maintain secrecy about the use and outcomes from R\&D activities necessarily generates significant information imbalances between lenders and debtors. Such asymmetries engender further uncertainty about the likely payoff from $R \& D$ investments to growth and profitability. Thus, the inability of creditors to distinguish between high and low-risk R\&D projects will cause them to ration loans (Stiglitz \& Weiss, 1981). Moreover, Hall (2002) found that "knowledge-intensive" firms are less levered "because the knowledge asset created by 
R\&D investment is intangible, partly embedded in human capital, and ordinarily very specialized to the particular firm which it resides... (p.8)."

The debate over the relative merits and impact of internally versus externally financed R\&D investment has evolved from one focused almost exclusively on the former factor to a more nuanced argument where equity finance is now recognized to play a critical role for young firms located in the American and European advanced technology sectors (Brown, Fazzari, \& Petersen, 2009; Carpenter \& Petersen, 2002a; Muller \& Zimmerman, 2006). However, questions about financing firm-level R\&D-especially across the industrialized economies, China and India - remain largely unanswered. While equity-financed R\&D investments are concentrated in the advanced technology sectors in the US, do we observe a similar pattern in other economies? Furthermore, does macroeconomic growth play a significant role in the determination of a businesses' R\&D investments? Evidence of both pro and countercyclical movements in the advanced economies have been described in the literature. Finally, do capital-intensive firms eschew R\&D investments because they tend to produce standardized products that do not rely upon proprietary production techniques and processes? Prior studies have not attempted to incorporate both macroeconomic demand and capital intensity into empirical models of equity-financed R\&D.

The objective of this study is to address these questions using expanded versions of the dynamic firm-level R\&D specifications estimated in Brown, Fazzari, and Petersen (2009); hereafter, "BF\&P." The literature on international comparisons of R\&D investments have largely confined themselves to a limited number of economic sectors either in the most advanced economies or China and India. Rapid economic growth in the latter two countries has been accompanied by significant increases in the number of college graduates with engineering, math, or science-based degrees. Moreover, notable gains in their technical human capital resources has also been associated with increases in the growth rate of private and public personnel engaged in $R \& D$ activities (OECD, 2012). The cumulative impact from both trends has been an acceleration in aggregate spending on R\&D. Figure 1 shows how China and India have undergone long-term gains in the share of inflation-adjusted GDP devoted to R\&D expenditures compared to the leading industrialized economies.

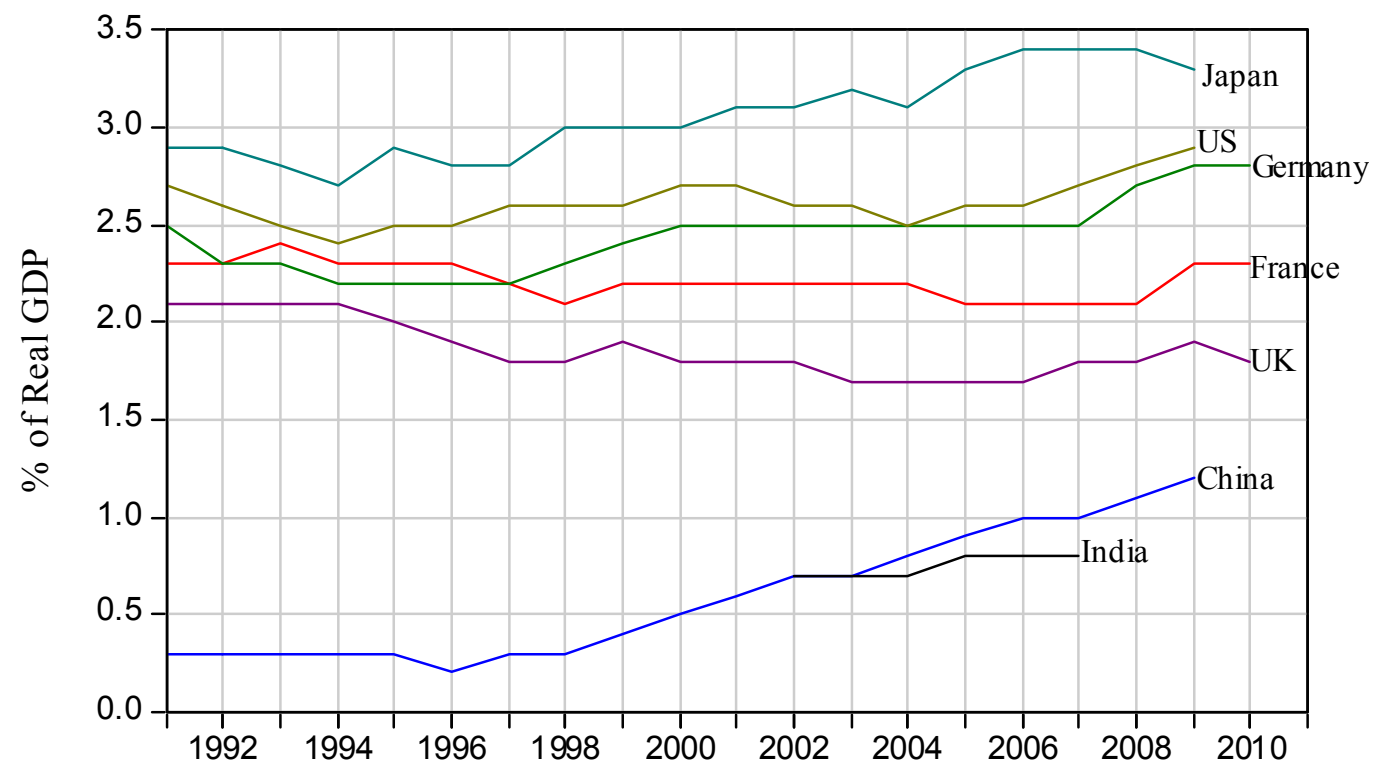

Figure 1. R\&D expenditures as share of real GDP

International comparisons of the impact of equity finance and other factors on firm-level R\&D investments have been difficult to analyze due to the lack of consistent cross-country data. However, the Thomson Financial Worldcope database standardizes their data for accounting, currency, and other differences to allow for the compilation of a broad sample of international firms. This study will employ an unbalanced panel sample of 53,740 firm-years across ten economic sectors located in China, France, Germany, Great Britain, India, Japan, and the US from 1998 through 2008. The proposed specification of R\&D expenditures will control for firm-level factors as well as inflation-adjusted aggregate growth in a firm's home country. We believe the latter influence represents a particularly novel contribution because each firm's panel now includes a time series of 
macroeconomic demand.

The next section summarizes the relevant literature on equity financing of $R \& D$ investments as well as the impact of the business cycle and firm-level capital intensity. Section 3 describes the relevant theoretical and empirical models; section 4 describes the panel data and presents the econometric results; and section 5 discusses the conclusions and implications of this investigation.

\section{Literature Review}

\subsection{Equity Finance}

The literature on equity-financed $R \& D$ expenditures is less extensive than that for debt financing, drawing upon ideas and results from the literature on financially constrained firms (e.g., Fazzari, Hubbard, \& Petersen, 1988; Lamont, 1997). Summaries in Schiantarelli (1995) and Hubbard (1998) note the dearth of research on the role of new equity finance to firm-level capital formation. Other studies have simply assumed that external finance is too expensive to fund investment (Greenwald \& Stiglitz, 1993). Himmelberg and Petersen (1994) analyzed the role of new equity issuance in US technology sectors and demonstrated that R\&D financing follows a hierarchy of funding with internal finance being less costly than debt or equity. In their model, the marginal cost of debt finance is initially zero up to some threshold dollar level (roughly equal to internal financial reserves). Above this amount, debt finance is employed but with an increasing marginal cost due to the higher likelihood of financial distress, adverse selection and moral hazard. However, as debt funding costs exceeds the "lemons premium" threshold (Akerlof, 1970), the marginal cost of debt and equity will become equalized such that new equity can be supplied at zero marginal cost (e.g., due to the absence of collateral requirements). While other studies have recognized similar types of financing hierarchies (Fazzari, Hubbard, \& Petersen, 1988; Carpenter \& Petersen, 2002a), they did not emphasize the implications of the highly elastic portion of the supply curve for equity finance: for relatively small but rapidly growing high-tech firms with little debt capacity, further growth "may be possible only if high-tech firms have access to external equity markets... and the size of the IPO may be very large relative to the size of the firm" (Carpenter \& Petersen, 2002b, p. F61). Using a panel of 2,400 US firms situated in the advanced technology sectors from 1981 through 1998, the authors found that most small high-tech companies did not use debt financing and that new equity capital was a significant source of R\&D funding relative to their physical capital stock.

The 2009 study by BF\&P explained a broad set of stylized facts and trends about American corporate spending on R\&D from 1990 to 2004. For example, about four fifths of total commercial R\&D spending in the US is largely concentrated in seven advanced technology industries including, pharmaceuticals, office and computing equipment, communications equipment, electronic components, scientific instrument, medical instruments, and computer software; the aerospace sector was excluded from their analysis due to the significant level of government-funded R\&D. Moreover, while all firms experienced a modest increase in R\&D spending since 1980, high-tech firms account for the vast majority of spending which was a record $1.89 \%$ of US GDP in 2000. The authors' core argument is that the 1990-2004 R\&D spending boom was due to a significant outward shift in the aggregate supply of internal and external funding. During this period, equity markets became the primary conduit for channeling new funds into R\&D investments made by young American high-tech firms.

To test their hypotheses, BF\&P constructed a panel dataset of 1,347 publicly traded US firms operating in the advanced technology sectors and listed in the Compustat database. Dynamic panel regression models were estimated using one-step General Method of Moments (GMM) estimation procedures developed in Arellano and Bond (1991), Bond et al. (2003), and Windmeijer (2005). BF\&P found that operating cash flow and net new equity issuance were significant determinants of R\&D expenditures for "young firms" (i.e., those with 15 years or less of quoted stock prices) but not mature firms. Furthermore, their sample of young high tech firms accounted for about three quarters of aggregate US R\&D expenditures.

\subsection{Additional Considerations}

\subsubsection{Macroeconomic Demand}

In their summary of findings, BF\&P emphasized how their work complements a large literature that establishes a significant correlation between macroeconomic indicators of financial development and economic growth (p. 180). Nevertheless, prior studies have not attempted to test the significance of a macroeconomic variable in a panel microeconometric model of R\&D investment. In the literature extant, the impact of macroeconomic demand on firm-level R\&D can be argued from two perspectives. On the one hand, cyclical downturns lower the firm's opportunity cost (in terms of foregone output) to engage in R\&D activities such that they are able to increase their technological capabilities and know-how during recessions. Agion and Saint-Paul (1998) advocate an "opportunity cost" or countercyclical argument of R\&D where the payoffs from productivity-enhancing activities occur after the 
contracting phase of a business cycle. Field (2003) persuasively argued that the 1930s was a period of substantial technological advancement among American firms that allowed for an unprecedented acceleration in armament production and aggregate output during the Second World War.

Alternatively, economic expansions typically provide firms with additional cash resources (e.g., increased sales and profits) which can be reinvested in R\&D activities. Aggregate data for R\&D expenditures across the advanced economies consistently show a pro-cyclical correlation between GDP growth and R\&D expenditures (Walde and Woitek, 2004). Using R\&D data from the US National Science Foundation (NSF), Rafferty (2003) and Comin and Gertler (2006) find both short and long-term patterns of procyclicality. Barlevey (2007) found a statistically significant association between the inflation-adjusted NSF data and real GDP growth. Thus, while the real GDP growth rate of the home country of each firm will be included in its respective panel, the expected sign is ambiguous because the literature supports both pro and counter-cyclical arguments of R\&D expenditures.

Another consideration from the literature on the cyclicality of R\&D investment is the range of temporal correlations with aggregate growth. For example, Barlevy (2007) found a significant contemporaneous association between real GDP and aggregate NSF data on R\&D investment. Walde and Woitek (2004) show correlation coefficients for lags and leads that range from -2 to +2 years. Ouyang (2008) found significant correlations between disaggregated R\&D expenditures and output growth for US firms using lags up to 2 years in length. Since the latter associations were based on firm-level data across different economic sectors whose "industry cycles are not fully synchronized with the aggregate cycles (p. 10)," we will test a range of lags on the real GDP regressor.

\subsubsection{Capital Intensity}

Though less prominent in the literature, capital intensity has also been identified as a determinant of R\&D expenditures. In their study of why firms would choose to invest in either internal or external R\&D activities, Audretsch et al. (1996) observed that in a world of risky payoffs, agency costs, and imperfect information, cooperative and/or outside contracting of $\mathrm{R} \& \mathrm{D}$ activity can be a rational response to such uncertainty. These analysts expect capital-intensive methods to be most prominent in non-technology sectors that produce "standardized products" under conditions of high entry costs and significant economies of scale. Since these firms require relatively less "asset-specific" human resources, the ratio of physical capital to the number of employees (i.e., the capital to labor ratio) is expected to be inversely related to internal R\&D investment (Ibid., p. 522). Indeed, the authors found a negative association between capital intensity and the likelihood of a low-tech firm engaging in internally-funded R\&D activities (Note 1 ).

Alternatively, where new knowledge is appropriable by the firm, the value of internal R\&D activities "is greater when it is undertaken in conjunction with the firm-specific human capital rather than independent of the firm-specific human capital (Ibid., p. 521)." Thus, firms located in technology and other skill-intensive sectors are expected to have higher rates of internal R\&D investments which should be positively associated with capital intensity. We will test both capital intensity hypotheses by using the lagged ratio of gross plant, property, and equipment to total employees as an additional regressor in the model. To that extent, a positive correlation is expected between R\&D expenditures in the knowledge-intensive technology sector, while an inverse association is expected in the other sectors that produce more standardized types of products.

\section{Model Specifications}

\subsection{Prior Models}

Empirical models of R\&D expenditures can be understood using Bond et al. (2003) structural Euler model of firm-level capital expenditures. The authors employed a dynamic investment model with symmetric quadratic adjustment costs which control for "expectational influences on the investment decision (p. 156)." The firm is assumed to maximize the net present value of future cash flows generated by investments in both physical capital as well as R\&D expenditures. Current investment in R\&D is assumed to be positively related to expected future profits and negatively related to the cost of capital which is captured by time and firm-specific effects. An output/capital ratio (proxied by sales/assets) is also introduced to capture either nonconstant returns to scale or a monopolistically competitive environment. Thus, Bond et. al. (2003) employed the following dynamic panel specification of capital expenditures:

$$
I_{i t+1} / K_{i t+1}=\beta_{1}\left(I_{i t} / K_{i t}\right)-\beta_{2}\left(I_{i t 1} / K_{i t l}\right)^{2}-\beta_{3}\left(\pi_{i t} / K_{i t}\right)+\beta_{4}\left(Y_{i t} / K_{i t}\right)+d_{t+1}+\eta_{i}+v_{i t+1}
$$

where I are capital expenditures for the $i$ th firm in the $t$ th time period, $\mathrm{K}$ is the gross capital stock, $\pi$ are gross operating profits, $\mathrm{Y}$ is output, $d_{t+1}$ is a time dummy variable, $\eta_{i}$ is a latent firm-specific effect and $v_{i t+l}$ is the panel error term. The authors show that under the null hypothesis of no financial constraints, $\beta_{1}$ and $\beta_{2}$ will be greater than or equal to $1, \beta_{3}$ will be greater than 0 , and $\beta_{4}$ will be greater than or equal to 0 if there are constant returns 
to scale. Evidence of a financially constrained firm would be observed by rejecting the null hypothesis such that "under the alternative hypothesis, investment spending is positively related to cash flow or profits through the effect of financial constraints (p. 157).

BF\&P applied their own version of the above equation to modeling $R \& D$ expenditures of US advanced technology firms. The authors underscore that a major difficulty when modeling financial constraints is distinguishing between variables that measure access to financing versus their role as proxies for expected profitability. They quote Bond et. al. (2003) in arguing that "current or lagged financial variables should not enter this specification merely as proxies for expected future profitability (p. 161)." In addition, the utility of a structural Euler model is that it eliminates the requirements for unobservable expectations and replaces them with actual values of explanatory variables plus a residual term. Empirically, the absence of financial constraints would be observed with insignificant coefficients on sales and net profits, respectively

$$
r d_{\mathrm{jt}}=\beta_{1} r d_{\mathrm{j}, \mathrm{t}-1}+\beta_{2} r d_{\mathrm{j}, \mathrm{t}-1}^{2}+\beta_{3} s_{\mathrm{j}, \mathrm{t}-1}+\beta_{4} c f_{\mathrm{j}, \mathrm{t}-1}+d_{t}+\alpha_{j}+v_{i j}
$$

where $r d$ is defined as a firm's R\&D expenses for the $j$ th firm in the $t$ th time period, $s$ are sales, $c f$ is gross cash flow defined as net income plus depreciation and R\&D expenses. All continuous variables are scaled by beginning-of-period assets with time $\left(d_{t}\right)$ and firm-fixed effects $\left(\alpha_{j}\right)$. The coefficients $\beta_{1}$ and $\beta_{2}$ are expected to be between +1 and -1 to capture autoregressive effects and quadratic adjustment costs, respectively. The lagged sales coefficient $\beta_{3}$ should be positive if conditions of imperfect competition prevail. The lagged cash flow coefficient, $\beta_{4}$ should be significantly greater than 0 under the assumption of constant returns to scale and factor payments equal to marginal products.

To test the impact of internal and external equity funding, BF\&P expand equation (2) to include contemporaneous and lagged values of sales, gross cash flow, and net stock issuance:

$$
r d_{\mathrm{jt}}=\beta_{1} r d_{\mathrm{j}, \mathrm{t}-1}+\beta_{2} r d_{\mathrm{j}, \mathrm{t}-1}^{2}+\beta_{3} s_{\mathrm{j}, \mathrm{t}}+\beta_{4} s_{\mathrm{j}, \mathrm{t}-1}+\beta_{5} c f_{\mathrm{j}, \mathrm{t}}+\beta_{6} c f_{\mathrm{j}, \mathrm{t}-1}+\beta_{7} s t k_{\mathrm{j}, \mathrm{t}}+\beta_{8} s t k_{\mathrm{j}, \mathrm{t}-1}+d_{t}+\alpha_{j}+v_{i j}
$$

Contemporaneous sales are included to control for firm demand and avoid possible specification bias on $\beta_{5}$ due to an association between cash flow and sales. Current $\left(s t k_{\mathrm{j}, t}\right)$ and lagged net stock issuance $\left(s t k_{\mathrm{j}, \mathrm{t}-1}\right)$ will test for short and longer-run effects of net equity finance on current R\&D expenses. RF\&P estimate equations (2) and (3) using first-difference GMM procedures developed by Arellano and Bond (1991) for dynamic autoregressive panel models of investment where all variables are endogenous and use three and four-year lagged levels as instruments.

\subsection{Econometric Specifications}

Dynamic panel GMM models will be estimated to analyze the impact of internal and equity finance on firm-level R\&D expenses across countries. We begin the modeling exercises by comparing estimates from BF\&P's "baseline" and "expanded" (i.e., including net stock issuance variables) Euler equation of $R \& D$ expenditures based upon investment models from Bond and Meghir (1994) and Bond et al. (2003). The advantage of the Euler approach is that the model can now "capture the influence of current expectations of future profitability on current investment decisions" (ibid., p. 153). Equation (4) is the "baseline" Euler dynamic panel specification and estimated in log-log form (as are all subsequent models):

$$
\begin{aligned}
& \mathrm{R} \& \mathrm{D}_{\mathrm{it}} / \text { Assets }_{\mathrm{it}}=\beta_{1} * \mathrm{R} \& \mathrm{D}_{\mathrm{it}-1} / \text { Assets }_{\mathrm{it}-1}+\beta_{2} *\left(\mathrm{R} \& \mathrm{D}_{\mathrm{it}-1} / \text { Assets }_{\mathrm{it}-1}\right)^{2}+\beta_{3} * \text { Sales }_{\mathrm{it}-1} / \text { Assets }_{\mathrm{it}-1}+\beta_{4} * \mathrm{CashFlow}_{\mathrm{it}-1} / \text { Assets }_{\mathrm{it}-1} \\
& +\alpha_{j}^{*} \operatorname{COUNTRY}_{j}+\delta_{t^{*}} \text { YEAR }_{t}+\varepsilon_{i t}
\end{aligned}
$$

where $R \& D_{i t} /$ Assets $_{i t}$ is the ratio of research and development $\left(R \& D_{i t}\right)$ expenditures to total assets $\left(A_{i t}\right)$ for the ith firm in the th year (Note 2). A positive coefficient is expected on the normalized lagged dependent variable $\left(R \& D_{i t-1} / A_{s s e t s}{ }_{i t-1}\right)$ due to the expected increase in profitability from $R \& D$ investments. Alternatively, a negative sign is expected on the proxy for the quadratic adjustment costs $\left(R \& D_{i t-1} / A_{s s e t} s_{i t-1}\right)^{2}$ associated with $R \& D$ expenses (BF\&P, 2009; Bond \& Meghir, 1994). Positive coefficients are expected on the lagged ratios of total sales to assets (Sales $\mathrm{it}_{\mathrm{i}-1} / \mathrm{Assets}_{\mathrm{it}-1}$ ) and net after tax income plus depreciation and R\&D expenses (Note 3) to assets (Cash Flow it- $\left.1_{1} / A_{\text {it-1 }}\right)$ due to imperfect competition and factor costs under conditions of constant returns to scale, respectively (BF\&P, 2009, p. 162). Since the new equation is estimating using international data on technology companies, COUNTRY is included as a dummy variable for the $j$ th country where a firm is located. Time dummies (YEAR) are also employed to control for "industry-specific changes in technological opportunities that could affect the demand for R\&D (ibid.)."

The "expanded" version of the above specification will test hypotheses about financing constraints as well as the impact of demand and access to net equity capital on R\&D expenditures. The new model accounts for access to internal funds as well as net equity capital using the contemporaneous and lagged values of sales, cashflow, and net stock issuance. Since the models will be estimated across years, countries, and economic sector, dummy variables for 
each category will also be included in the specification. Therefore, the following dynamic panel model using GMM techniques will be estimated :

$$
\begin{aligned}
& R \& D_{i t} / \text { Assets }_{i t}=\beta_{1} * R \& D_{i t-1} / \text { Assets }_{i t-1}+\beta_{2} *\left(R \& D_{i t-1} / \text { Assets }_{i t-1}\right)^{2}+\beta_{3} * \text { Sales }_{i t} / \text { Assets }_{i t}+\beta_{4} * \text { Sales }_{i t-1} / \text { Assets }_{i t-1}+ \\
& \beta_{5}{ }^{*} \text { Cash Flow }_{i t} \text { Assets }_{i t}+\beta_{6}{ }^{*} \text { Cash Flow }_{i t-1} / A_{i t-1}+\beta_{7} * \text { Net Stock Issuance } t / \text { Assets }_{i t}+\beta_{8} * \text { Net Stock } \\
& \text { Issuance }_{i t-1} / \text { Assets }_{i t-1}+\delta_{t}^{*} \text { YEAR }_{t}+\alpha_{j}^{*} \text { COUNTRY }_{j}+\gamma_{k}^{*} \text { DJ SECTOR } k+\varepsilon_{i t}
\end{aligned}
$$

where Net Stock Issuance is the difference between new stock issuances and repurchases and DJ SECTOR is a dummy variable for the $k$ th Dow Jones economic sector. Given that any firm's time series is limited to no more than eleven years inclusive, it is not possible to reproduce BF\&P's distinction between "mature" and "young" firms. On the other hand, since most of the Chinese and Indian firms were not part of the Worldscope database before 1998, these firms are likely to be relatively younger than the average firm included in the sample.

\subsection{Augmented Specification}

As was noted above, the relatively short time series for Chinese and Indian firms precludes testing for differences according to firm tenure. However, two new explanatory variables suggested in the R\&D literature will be added to the model: macroeconomic demand and capital intensity. The following specification will be estimated for the aggregate sample as well for the technology sector:

$$
\begin{aligned}
& R \& D_{i t} / \text { Assets }_{i t}=\beta_{1} * R \& D_{i t-1} / \text { Assets }_{i t-1}+\beta_{2} *\left(R \& D_{i t-1} / \text { Assets }_{i t-1}\right)^{2}+\beta_{3} * \text { Sales }_{i t} / A_{i t}+\beta_{4} * \text { Sales }_{i t-1} / A_{i t-1}+\beta_{5} * \text { Cash } \\
& \text { Flow }_{i t} / \text { Assets }_{i t}+\beta_{6}{ }^{*} \text { Cash Flow }_{i t-1} / \text { Assets }_{i t-1}+\beta_{7} * \text { Net Stock Issuance }_{i t} / \text { Assets }_{i t}+\quad \beta_{8} * \text { Net Stock Issuance }_{i t-1} / \text { Assets }_{i t-1} \\
& +\beta_{11} * R G D P_{i t-1}+\beta_{12} * K L_{i t-1}+\delta_{t^{*}} Y_{E A R_{t}}+\alpha_{j}^{*} \text { COUNTRY } Y_{j} \gamma_{k}^{* D J} \text { SECTOR }_{k}+\varepsilon_{i t}
\end{aligned}
$$

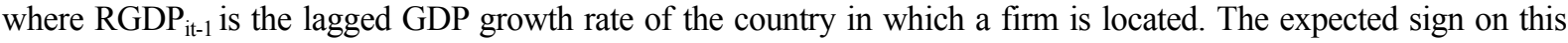
variable is ambiguous: while several studies suggest a procyclical association between R\&D expenses and macroeconomic growth, the "opportunity cost" hypothesis suggests that firms increase R\&D expenditures during economic downturns. In order to the impact of firm-level capital intensity, the lagged ratio of gross investment in plant, property, and equipment to the total number of employees $\left(\mathrm{KL}_{\mathrm{it}-1}\right)$ will be employed. A positive association with R\&D expenditures is expected for the knowledge-intensive technology sector. For "low-tech" sectors that typically produce more standardized products using methods and techniques that rely less on firm-specific human capital (and more on generic or easily reproducible production methods), we expect a negative association between R\&D expenses and a firm's capital to labor ratio. (Audretsch et al., 1996).

\section{Data and Econometric Results}

\subsection{Data}

The econometric models will use firm-level data from 1998 through 2008 for non-financial, non-utility publicly-traded companies located in China, France, Germany, Great Britain, India, Japan, and the United States. Each business is also identified according to a Dow Jones economic sector code noted in the Thomson Financial Worldscope database. The time period was selected to capture the introduction of Chinese and Indian firms into the Worldscope database and to avoid distortions caused by the financial crisis of 2009. Descriptive statistics for panel data can be better understood if average values are presented separately by year and economic sector. Thus, Table 1a presents the mean value for each continuous variable based on the number of firm-year observations ("N") by country (Panel A) and year (Panel B); table 1b presents mean values by economic sector across all countries (Panel A) and US firms (Panel B). 
Table 1a. Mean panel data by country and year

Panel A. ( $\mathrm{N}=$ Firm-Years)

\begin{tabular}{lllllll}
\hline & R\&D/ & Sales/ & Cashflow/ & $\begin{array}{l}\text { Net Stock } \\
\text { Issuance/ }\end{array}$ & Gross PP\&E/ & Real GDP \\
\hline Country & Assets & Assets & Assets & Assets & Employees & Growth Rate \\
China & 0.012 & 0.826 & 0.138 & 0.058 & 0.104 & 9.35 \\
$\mathrm{~N}$ & 1,214 & 1,214 & 1,214 & 1,026 & 860 & 1,214 \\
Germany & 0.059 & 1.111 & 0.122 & 0.030 & 0.153 & 1.80 \\
$\mathrm{~N}$ & 1,910 & 1,910 & 1,910 & 1,351 & 1,883 & 1,910 \\
France & 0.058 & 0.963 & 0.127 & 0.023 & 0.148 & 1.90 \\
$\mathrm{~N}$ & 1,251 & 1,251 & 1,251 & 929 & 1,204 & 1,251 \\
Great Britain & 0.078 & 1.031 & 0.102 & 0.098 & 0.128 & 2.93 \\
$\mathrm{~N}$ & 3,074 & 3,071 & 3,074 & 3,030 & 3,044 & 3,074 \\
India & 0.005 & 1.026 & 0.137 & 0.021 & 0.108 & 6.96 \\
$\mathrm{~N}$ & 3,721 & 3,718 & 3,721 & 3,308 & 1,647 & 3,721 \\
Japan & 0.021 & 1.039 & 0.104 & 0.004 & 0.301 & 0.64 \\
$\mathrm{~N}$ & 17,352 & 17,352 & 17,352 & 9,853 & 17,255 & 17,352 \\
USA & 0.070 & 1.091 & 0.111 & 0.059 & 0.260 & 2.21 \\
$\mathrm{~N}$ & 25,218 & 25,209 & 25,218 & 24,461 & 3,580 & 25,218 \\
Total & 0.048 & 1.058 & 0.111 & 0.045 & 0.252 & 2.21 \\
$\mathrm{~N}$ & 53,740 & 53,725 & 53,740 & 43,958 & 49,473 & 53,740 \\
\hline
\end{tabular}

Panel B.

\begin{tabular}{|c|c|c|c|c|c|c|}
\hline Year & $\begin{array}{l}\mathrm{R} \& \mathrm{D} / \\
\text { Assets }\end{array}$ & $\begin{array}{l}\text { Sales/ } \\
\text { Assets }\end{array}$ & $\begin{array}{l}\text { Cashflow/ } \\
\text { Assets }\end{array}$ & $\begin{array}{l}\text { Net Stock } \\
\text { Issuance/ } \\
\text { Assets }\end{array}$ & $\begin{array}{l}\text { Gross PP\&E/ } \\
\text { Employees }\end{array}$ & $\begin{array}{l}\text { Real GDP } \\
\text { Growth Rate }\end{array}$ \\
\hline 1998 & 0.065 & 1.073 & 0.119 & 0.067 & 0.206 & 3.82 \\
\hline $\mathrm{N}$ & 3,021 & 3,018 & 3,021 & 2,378 & 2,720 & 3,021 \\
\hline 1999 & 0.056 & 1.023 & 0.116 & 0.08 & 0.214 & 3.36 \\
\hline $\mathrm{N}$ & 3,084 & 3,083 & 3,084 & 2,452 & 3,084 & 2,811 \\
\hline 2000 & 0.049 & 1.02 & 0.109 & 0.085 & 0.199 & 3.12 \\
\hline $\mathrm{N}$ & 3,629 & 3,625 & 3,629 & 3,253 & 3,629 & 3,387 \\
\hline 2001 & 0.055 & 1.029 & 0.1 & 0.047 & 0.192 & 1.21 \\
\hline $\mathrm{N}$ & 3,925 & 3,924 & 3,925 & 3,575 & 3,925 & 3,638 \\
\hline 2002 & 0.059 & 1.046 & 0.099 & 0.033 & 0.192 & 1.19 \\
\hline $\mathrm{N}$ & 4,332 & 4,331 & 4,332 & 3,942 & 4,332 & 4,047 \\
\hline 2003 & 0.051 & 1.064 & 0.108 & 0.036 & 0.222 & 1.89 \\
\hline $\mathrm{N}$ & 5,311 & 5,310 & 5,311 & 4,281 & 5,311 & 4,989 \\
\hline 2004 & 0.049 & 1.067 & 0.119 & 0.06 & 0.244 & 3.32 \\
\hline $\mathrm{N}$ & 5,696 & 5,695 & 5,696 & 4,572 & 5,696 & 5,308 \\
\hline 2005 & 0.048 & 1.067 & 0.12 & 0.049 & 0.233 & 2.87 \\
\hline $\mathrm{N}$ & 5,978 & 5,978 & 5,978 & 4,758 & 5,978 & 5,575 \\
\hline 2006 & 0.042 & 1.046 & 0.117 & 0.045 & 0.243 & 3.58 \\
\hline $\mathrm{N}$ & 6,737 & 6,734 & 6,737 & 5,417 & 6,737 & 6,025 \\
\hline 2007 & 0.032 & 1.07 & 0.095 & 0.02 & 0.329 & 2.87 \\
\hline $\mathrm{N}$ & 6,084 & 6,084 & 6,084 & 4,796 & 6,084 & 5,568 \\
\hline 2008 & 0.045 & 1.096 & 0.12 & 0.01 & 0.397 & -2 \\
\hline $\mathrm{N}$ & 5,943 & 5,943 & 5,943 & 4,534 & 5,943 & 5,405 \\
\hline Totals & 0.048 & 1.058 & 0.111 & 0.045 & 0.252 & 2.21 \\
\hline $\mathrm{N}$ & 53,740 & 53,725 & 53,740 & 43,958 & 53,740 & 49,473 \\
\hline
\end{tabular}

Table 1b shows that the mean panel ratios for US technology companies included in this study compare favorably to BF\&P's "mature" cohort of firms for the ratios of R\&D/assets (0.11 vs. 0.098 in BF\&P), sales/assets 
(0.96 vs. 1.17$)$ and net stock issuance/assets (0.07 vs. 0.02$)$.

Table 1b. Mean panel data by sector and US firms

Panel A. ( $\mathrm{N}=$ Firm-Years)

\begin{tabular}{|c|c|c|c|c|c|}
\hline Sector & $\begin{array}{l}\mathrm{R} \& \mathrm{D} / \\
\text { Assets }\end{array}$ & $\begin{array}{l}\text { Sales/ } \\
\text { Assets }\end{array}$ & $\begin{array}{l}\text { Cashflow/ } \\
\text { Assets }\end{array}$ & $\begin{array}{l}\text { Net Stock } \\
\text { Issuance/ } \\
\text { Assets }\end{array}$ & $\begin{array}{l}\text { Gross PP\&E/ } \\
\text { Employees }\end{array}$ \\
\hline Basic Materials & 0.02 & 0.944 & 0.118 & 0.015 & 0.428 \\
\hline $\mathrm{N}$ & 5,189 & 5,187 & 5,189 & 4,071 & 4,657 \\
\hline Consumer - Cylical & 0.023 & 1.281 & 0.119 & 0.02 & 0.164 \\
\hline $\mathrm{N}$ & 8,603 & 8,602 & 8,603 & 7,195 & 7,893 \\
\hline Consumer - Noncyclical & 0.014 & 1.3 & 0.12 & 0.009 & 0.222 \\
\hline $\mathrm{N}$ & 4,126 & 4,126 & 4,126 & 3,308 & 3,805 \\
\hline Energy & 0.006 & 1.004 & 0.134 & 0.05 & 1.707 \\
\hline $\mathrm{N}$ & 1,438 & 1,438 & 1,438 & 1,357 & 1,271 \\
\hline Healthcare & 0.125 & 0.78 & 0.081 & 0.114 & 0.119 \\
\hline $\mathrm{N}$ & 5,783 & 5,778 & 5,783 & 5,134 & 5,341 \\
\hline Industrial & 0.021 & 1.094 & 0.106 & 0.017 & 0.22 \\
\hline $\mathrm{N}$ & 13,291 & 13,288 & 13,291 & 10,187 & 12,602 \\
\hline Independent & 0.011 & 1.169 & 0.1 & 0.011 & 0.314 \\
\hline $\mathrm{N}$ & 226 & 225 & 226 & 171 & 190 \\
\hline Technology & 0.087 & 1.005 & 0.124 & 0.061 & 0.105 \\
\hline $\mathrm{N}$ & 12,405 & 12,403 & 12,405 & 10,145 & 11,880 \\
\hline Telecommunications & 0.013 & 0.704 & 0.126 & 0.03 & 0.699 \\
\hline $\mathrm{N}$ & 560 & 560 & 560 & 523 & 509 \\
\hline Other & 0.065 & 0.918 & 0.069 & 0.15 & 0.819 \\
\hline $\mathrm{N}$ & 2,119 & 2,118 & 2,119 & 1,867 & 1,325 \\
\hline Total & 0.048 & 1.058 & 0.111 & 0.045 & 0.252 \\
\hline $\mathrm{N}$ & 53,740 & 53,725 & 53,740 & 43,958 & 49,473 \\
\hline
\end{tabular}

Panel B.

\begin{tabular}{llllll}
\hline Sector - US Firms & & & & & \\
\hline Basic Materials & 0.028 & 0.95 & 0.123 & 0.022 & 0.344 \\
$\mathrm{~N}$ & 1,428 & 1,427 & 1,428 & 1,400 & 1,366 \\
Consumer - Cylical & 0.024 & 1.458 & 0.122 & 0.022 & 0.091 \\
$\mathrm{~N}$ & 4,096 & 4,095 & 4,096 & 3,990 & 3,859 \\
Consumer - Noncyclical & 0.017 & 1.429 & 0.13 & 0.012 & 0.128 \\
$\mathrm{~N}$ & 1,659 & 1,659 & 1,659 & 1,627 & 1,604 \\
Energy & 0.006 & 0.939 & 0.135 & 0.057 & 1.916 \\
$\mathrm{~N}$ & 1,096 & 1,096 & 1,096 & 1,044 & 963 \\
Healthcare & 0.149 & 0.793 & 0.062 & 0.133 & 0.103 \\
$\mathrm{~N}$ & 3,753 & 3,748 & 3,753 & 3,646 & 3,554 \\
Industrial & 0.029 & 1.266 & 0.124 & 0.022 & 0.245 \\
$\mathrm{~N}$ & 4,607 & 4,607 & 4,607 & 4,479 & 4,417 \\
Independent & 0.001 & 0.986 & 0.105 & 0.01 & 0.296 \\
$\mathrm{~N}$ & 48 & 48 & 48 & 48 & 41 \\
Technology & 0.114 & 0.96 & 0.123 & 0.066 & 0.103 \\
$\mathrm{~N}$ & 6,881 & 6,879 & 6,881 & 6,695 & 6,570 \\
Telecommunications & 0.01 & 0.656 & 0.123 & 0.029 & 0.667 \\
$\mathrm{~N}$ & 421 & 421 & 421 & 404 & 377 \\
Other & 0.098 & 0.85 & 0.036 & 0.193 & 1.059 \\
$\mathrm{~N}$ & 1,229 & 1,229 & 1,229 & 1,128 & 829 \\
Total & 0.07 & 1.091 & 0.111 & 0.059 & 0.26 \\
$\mathrm{~N}$ & 25,218 & 25,209 & 25,218 & 24,461 & 23,580 \\
\hline
\end{tabular}


Table 2 displays the correlation coefficient matrix for all the continuous variables used in the dynamic panel econometric models. Nearly all the correlation coefficients have values less than 0.50 and thus there is a low probability that the models suffer from multicollinearity.

Table 2. Correlation coefficients

\begin{tabular}{|c|c|c|c|c|c|c|c|c|c|c|c|}
\hline & & & & & & & & Net & Net & & \\
\hline & & & & & & Cash & Cash & Stock & Stock & & \\
\hline & $\mathrm{R} \& \mathrm{D}(\mathrm{t}) /$ & $\mathrm{R} \& \mathrm{D}(\mathrm{t}-1) /$ & {$[(\mathrm{R} \& \mathrm{D}(\mathrm{t}-1) /$} & Sales $(\mathrm{t}) /$ & Sales(t-1)/ & Flow(t)/ & Flow(t-1)/ & Issuance $(\mathrm{t}) /$ & Issuance(t-1)/ & & \\
\hline & Assets $(\mathrm{t})$ & Assets(t-1) & Assets(t-1)]2 & Assets(t) & Assets $(\mathrm{t}-1)$ & Assets(t) & Assets(t-1) & Assets(t) & Assets(t-1) & $\% \Delta \operatorname{RGDP}(\mathrm{t}-2)$ & $\mathrm{KL}(\mathrm{t}-1)$ \\
\hline$R \& D(t) / \operatorname{Assets}(t)$ & 1.000 & & & & & & & & & & \\
\hline $\mathrm{R} \& \mathrm{D}(\mathrm{t}-1) /$ Assets(t-1) & 0.506 & 1.000 & & & & & & & & & \\
\hline$[(\mathrm{R} \& \mathrm{D}(\mathrm{t}-1) / \operatorname{Assets}(\mathrm{t}-1)] 2$ & 0.115 & 0.784 & 1.000 & & & & & & & & \\
\hline Sales $(\mathrm{t}) / \operatorname{Assets}(\mathrm{t})$ & -0.115 & -0.096 & -0.018 & 1.000 & & & & & & & \\
\hline Sales(t-1)/Assets(t-1) & -0.014 & -0.007 & -0.001 & 0.077 & 1.000 & & & & & & \\
\hline Cash Flow/(t)Assets(t) & -0.180 & -0.125 & -0.048 & 0.147 & 0.015 & 1.000 & & & & & \\
\hline Cash Flow(t-1)/Assets(t-1) & -0.015 & -0.011 & -0.002 & 0.006 & 0.009 & 0.045 & 1.000 & & & & \\
\hline Net Stock Issuance(t)/Assets(t) & 0.306 & 0.355 & 0.128 & -0.168 & -0.010 & -0.388 & -0.060 & 1.000 & & & \\
\hline Net Stock Issuance(t-1)/Assets(t-1) & 0.285 & 0.539 & 0.419 & -0.121 & -0.127 & -0.320 & -0.087 & 0.364 & 1.000 & & \\
\hline$\% \Delta \operatorname{RGDP}(\mathrm{t}-2)$ & 0.008 & 0.013 & 0.009 & -0.010 & 0.002 & 0.030 & -0.002 & 0.060 & 0.052 & 1.000 & \\
\hline $\mathrm{KL}(\mathrm{t}-1)$ & -0.032 & -0.020 & -0.002 & -0.051 & -0.051 & 0.005 & 0.000 & -0.003 & 0.003 & -0.017 & 1.000 \\
\hline
\end{tabular}

\subsection{Dynamic Panel GMM Estimation}

The econometric panel models are estimated using STATA's "xtabond2" procedures which incorporate the first-difference GMM methodology developed by Arrelano and Bond (1991). Their methodology corrects for panel estimation problems when using lagged dependent variables and fixed effects as explanatory variables. Employing Ordinary Least Squares (OLS) estimation will generate serially correlated error terms while fixed effects will also be correlated with the explanatory variables. However, by differencing all variables, the firm fixed-effect is removed and the new differenced lagged dependent variable becomes an instrument for its past level values. Furthermore, by treating all explanatory variables as potentially endogenous, Arrelano and Bond's method avoids problems associated with simultaneous equation bias arising from specification error. Following estimation protocols in Bond et. al. (2003) and Ughetto (2008), instruments will include all independent variables lagged two years. Finally, in a dynamic panel dataset with a large number of cross sections (firms) but a small number of time series (years) per firm, a shock to a firm's fixed effects would likely manifest in significant serial correlation. Differencing typically corrects this problem, however, tests for serial correlation in the error term will be performed.

\subsection{Baseline and Expanded Models}

Model 1 in Table 3 displays the "baseline" results from BF\&P's equation (4) specification which employed a panel sample of US high-tech firms drawn from the Compustat database from 1990-2004. Model 3 are new estimates from a panel of Chinese, French, German, Indian, Japanese, UK, and US technology companies from 1998 to 2008 gleaned from the Thomson Financial Worldscope database. The lagged and squared lagged value of the dependent variable had similarly significant signs, suggesting that both model 1 and 3 can account for profit expectations and quadratic adjustments costs. However, unlike model 1, the significant lagged sales and cash flow coefficients confirm the importance of firm-level demand and internal finance in the presence of imperfectly competitive conditions (BF\&P, 2009, p. 162). The country dummy variables in model 3 indicate below-average ratios of R\&D to assets in every country relative to the US; only Great Britain did not exhibit a statistically significant coefficient. Summary $p$-value tests for second-order residual correlation in the differenced residuals are acceptable (Note 4). Similar to BF\&P's baseline model, the Hansen tests reject the validity of the instruments. 
Table 3. US Technology companies and all countries and sectors

\begin{tabular}{|c|c|c|c|c|c|c|c|c|c|c|c|c|}
\hline & \multicolumn{4}{|c|}{ Brown, Fazzari, Petersen (2009) } & \multicolumn{4}{|c|}{ Technology - All Countries } & \multicolumn{4}{|c|}{ All Countries \& Sectors } \\
\hline \multicolumn{13}{|c|}{ Dependent Variable: $\quad R \& D_{(i t)} /$ Assets $_{(i t)}$} \\
\hline \multirow[t]{2}{*}{ Model: } & \multicolumn{2}{|c|}{$\begin{array}{c}1 \\
\text { (Baseline) }\end{array}$} & \multicolumn{2}{|c|}{$\begin{array}{c}\mathbf{2} \\
\text { (Expanded) }\end{array}$} & \multicolumn{2}{|c|}{$\begin{array}{c}3 \\
\text { (Baseline) }\end{array}$} & \multicolumn{2}{|c|}{$\begin{array}{c}4 \\
\text { (Expanded) }\end{array}$} & \multicolumn{2}{|c|}{$\begin{array}{c}5 \\
\text { (Baseline) }\end{array}$} & \multicolumn{2}{|c|}{$\begin{array}{c}6 \\
\text { (Expanded) }\end{array}$} \\
\hline & $\beta$ & t-stat & $\beta$ & t-stat & $\beta$ & t-stat & $\beta$ & t-stat & $\beta$ & t-stat & $\beta$ & t-stat \\
\hline \multicolumn{13}{|l|}{ Independent Variables: } \\
\hline$R \& D_{(t-1)} / \operatorname{Assets}_{(t-1)}$ & 0.808 & $3.76^{* * *}$ & 0.380 & $2.84^{* * *}$ & 0.294 & $3.87^{* * *}$ & 0.218 & $3.28^{* * *}$ & 0.359 & $6.85^{* * *}$ & 0.280 & $6.16^{* * *}$ \\
\hline 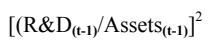 & -0.400 & $-2.88^{* * *}$ & -0.145 & $-1.91 * *$ & -0.020 & $-3.62 * * *$ & -0.013 & $-3.26^{* * *}$ & -0.019 & $-3.95^{* * *}$ & -0.014 & $-3.5 * * *$ \\
\hline Sales $_{(t)} / \operatorname{Assets}_{(t)}$ & & & -0.020 & -1.11 & & & 0.004 & 0.190 & & & 0.004 & 0.61 \\
\hline $\operatorname{Sales}_{(t-1)} / \operatorname{Assets}_{(t-1)}$ & -0.007 & -0.04 & -0.015 & $-1.67 * *$ & 0.025 & $2.09^{* *}$ & 0.010 & 0.850 & 0.008 & 0.45 & -0.002 & $-1.9^{*}$ \\
\hline Cash Flow/(t) Assets $_{(t)}$ & & & 0.170 & $4.15^{* * *}$ & & & 0.000 & -0.480 & & & 0.000 & -0.25 \\
\hline $\begin{array}{l}\text { Cash } \\
\text { Flow }_{(t-1)} / \operatorname{Assets}_{(t-1)}\end{array}$ & -0.015 & -0.33 & 0.001 & 0.06 & 0.001 & $1.69 *$ & 0.000 & 0.930 & 0.000 & 0.95 & 0.000 & -0.9 \\
\hline $\begin{array}{l}\text { Net Stock } \\
\text { Issuance }_{(t)} / \text { Assets }_{(t)}\end{array}$ & & & 0.151 & $8.88^{* * *}$ & & & 0.163 & $4.23^{* * *}$ & & & 0.143 & $3.41^{* * *}$ \\
\hline $\begin{array}{l}\text { Net Stock } \\
\text { Issuance }_{(t-1)} / \text { Assets }_{(t-1)}\end{array}$ & & & -0.018 & $-4.5 * * *$ & & & -0.042 & $-3.51^{* * *}$ & & & -0.013 & -0.94 \\
\hline \multicolumn{13}{|l|}{ Country } \\
\hline China & & & & & -0.054 & $-6.85^{* * *}$ & -0.064 & $-8.14^{* * *}$ & -0.027 & $-4.72 * * *$ & -0.033 & $-9.55^{* * *}$ \\
\hline France & & & & & -0.019 & $-2.33^{* *}$ & -0.015 & $-1.64 *$ & -0.001 & -0.15 & -0.002 & -0.5 \\
\hline Germany & & & & & -0.027 & $-3.97 * * *$ & -0.028 & $-3.73 * * *$ & -0.006 & $-1.94 * *$ & -0.006 & $-1.82 *$ \\
\hline Great Britain & & & & & 0.002 & 0.29 & -0.004 & -0.46 & 0.003 & 0.96 & 0.000 & 0.06 \\
\hline India & & & & & -0.069 & $-7.98^{* * *}$ & -0.078 & $-9.5 * * *$ & -0.031 & $-9.06^{* * * *}$ & -0.030 & $-11.62 * * *$ \\
\hline Japan & & & & & -0.059 & $-8.3^{* * *}$ & -0.061 & $-9.62 * * *$ & -0.019 & $-6.32 * * *$ & -0.016 & $-7.9^{* * *}$ \\
\hline \multicolumn{13}{|l|}{ Industry } \\
\hline Basic Materials & & & & & & & & & -0.021 & $-3.46^{* * *}$ & -0.005 & -0.75 \\
\hline Consumer - Cylical & & & & & & & & & -0.027 & $-3.06^{* * *}$ & -0.009 & -1.3 \\
\hline $\begin{array}{l}\text { Consumer } \\
\text { Noncyclical }\end{array}$ & - & & & & & & & & -0.031 & $-3.29 * * *$ & -0.013 & $-1.81 *$ \\
\hline Energy & & & & & & & & & -0.040 & $-5.6^{* * *}$ & -0.026 & $-4.01 * * *$ \\
\hline Healthcare & & & & & & & & & 0.033 & $4.74^{* * *}$ & 0.048 & $7.09^{* * *}$ \\
\hline Industrial & & & & & & & & & -0.025 & $-3.49^{* * *}$ & -0.007 & -0.99 \\
\hline Independent & & & & & & & & & -0.026 & $-3.03 * * *$ & -0.012 & $-1.72 *$ \\
\hline Technology & & & & & & & & & 0.013 & $2.35^{* *}$ & 0.037 & $5.69^{* * *}$ \\
\hline Telecommunications & & & & & & & & & -0.035 & $-4.39 * * *$ & -0.021 & $-2.71 * * *$ \\
\hline $\mathrm{m} 1$ (p-value) & & 0.000 & & 0.000 & & 0.001 & & 0.000 & & 0.003 & & 0.000 \\
\hline $\mathrm{m} 2$ (p-value) & & 0.401 & & 0.249 & & 0.955 & & 0.330 & & 0.396 & & 0.186 \\
\hline Hansen (p-value) & & 0.002 & & 0.000 & & 0.000 & & 0.000 & & 0.126 & & 0.000 \\
\hline Firm-Years & & 12,248 & & 12,248 & & 10,687 & & 8,755 & & 45,227 & & 36,636 \\
\hline Firms & & 1,347 & & 1,347 & & 1,547 & & 1,214 & & 7,267 & & 5,905 \\
\hline
\end{tabular}

Note. Estimates are produced by the Arellano-Bond one-step difference Generalized Method of Moments (GMM) with robust standard errors. All instruments include up to 2-year lags. Hansen (p-value) of overidentifying restrictions; $\operatorname{Pr}>|\mathrm{m} 1|$ and $\operatorname{Pr}>|\mathrm{m} 2|$ are the Arellano-Bond tests of first and second order residual serial correlation.

* Significant at $<0.10$ level. ** Significant at $<0.05$ level. *** Significant at $<0.01$ level.

In order to test the role of financing constraints on R\&D expenses, equation (2) includes additional variables to proxy a firm's access to both internal finance and external equity funding. Models 2 and 4 compare the original and re-estimated "expanded" Euler equations, respectively. Once again, both models had significant lagged and lagged squared dependent variables that conformed to their expected signs. Unlike current cash flow, the contemporaneous sales coefficient was not significant in model 2 and neither variable was significant in model 4 . The most consistent finding for models 2 and 4 was the significant contemporaneous (0.151 vs. 0.163$)$ and lagged (-0.018 vs. -0.042$)$ coefficients for the net stock issuance variable, respectively. The former coefficients indicate that, on average, firms invest about $15 \%-16 \%$ of new equity funds in R\&D; Ughetto (2008) also obtained similar percentages in models of 
R\&D expenditures for Italian firms. While the lack of significance of the contemporaneous cash flow variable precludes support for BF\&P's hypothesis of binding financial constraints, equity financing is a significant source of funding for R\&D expenditures. This is not surprising because our sample consists of a mix of both mature and young firms where the latter are more likely to face binding financial constraints. On the other hand, even mature firms located in rapidly expanding economies are likely to gain access to equity financing from their burgeoning stock markets and accelerating financial liberalization. Indeed, publicly traded firms in China are found to have both higher R\&D intensity and labor productivity relative to state owned enterprises (Zhang et al., 2003).

This study also seeks to test whether the determinants of R\&D expenditures are relevant to economic sectors across the advanced and rapidly developing economies. Models 5 and 6 in table 3 display the results for both the baseline and expanded equations which are estimated across the entire sample of sectors and countries. Similar to models 3 and 4, these models had significant lagged and lagged squared dependent variables, plus the dummy country variables exhibited comparable signs and significance levels. In model 6, the contemporaneous net stock issuance variable was the only additionally significant regressor. The lack of significance of the contemporaneous sales and cash flow variables may be due to the heterogeneous ages of firms, some of whom may or may not be financially constrained. Valid instruments are confirmed for the new baseline estimates across all sectors (model 5) but not for the expanded model (model 6). Thus, similar estimates from the full-sample as well as the technology sector provides the motivation for testing an augmented model of R\&D expenditures.

\subsection{Augmented Specifications}

\subsubsection{By Country-All Sectors}

Table 4 displays the estimates of equation (6) for the aggregate sample as well as individual countries. Model (1) shows the full-sample results estimated across all sectors. As with the prior full-sample specifications, the lagged and lagged squared dependent variables are significant and have the expected signs. Contemporaneous sales are significant while lagged sales are negative and significant; gross cash flow was not a statistically significant explanatory variable. Net stock issuance and lagged GDP growth are both positive and significant while the capital labor ratio had a negative and significant coefficient. The significant country dummy variables in model (1) imply that firms located in China, India and Japan had below-average R\&D expenditures relative to US firms. Healthcare and technology companies also had above-average R\&D expenditures relative to the excluded ("other") category.

Results for individual countries did not generate as consistent results compared to those based on the entire sample. The most consistent-cross country results were for US firms which represent just under three-fifths (57\%) of total firm-year observations. The most important result was that net stock issuance was significant and positive with a coefficient (0.17) nearly equal to that estimated by BF\&P (0.15). Although the capital labor ratio was statistically significant, it had a negligibly small coefficient. The positive sign on lagged real GDP underscores the importance of macroeconomic growth to commercial R\&D investment. The insignificant coefficients on the gross cash flow variables were consistent with BF\&P's findings of "no binding constraints" for non-technology companies and confirmed an "absence of a finance-driven R\&D boom beyond the seven high-tech industries (p. 178)".

Among the other countries, the most consistent result is for contemporaneous sales which had a positive and significant impact on every economy except France and India. Cash flow was insignificant across all countries except for Germany and Great Britain where it had the wrong (i.e., negative) sign. There was no consistent pattern to net stock issuance, with significant negative contemporaneous coefficients for firms located in China, Great Britain, and Japan. On the other hand, significant positive values on lagged net stock issuance for France and Great Britain suggest a longer-term salutary effect from equity-funded R\&D. Macroeconomic growth had a positive impact across all economies but is statistically significant only in Germany, Great Britain, and the US. Capital intensity had a negative coefficient across all seven countries but had a significant coefficient only for US firms. Since non-technology companies are assumed to produce relatively more standardized products with less knowledge-intensive techniques, an inverse association between R\&D investment and the capital labor ratio is confirmed. Additionally, government-funded or external R\&D investments may be substituting for some expenditures across the non-technology sectors. 
Table 4. All sectors

\begin{tabular}{|c|c|c|c|c|c|c|c|c|}
\hline & \multicolumn{2}{|c|}{ All Countries } & \multicolumn{2}{|l|}{ China } & \multicolumn{2}{|l|}{ France } & \multicolumn{2}{|c|}{ Germany } \\
\hline \multicolumn{9}{|c|}{ Dependent Variable: $R \& D_{(i t)} / A_{s s e t s}(i t)$} \\
\hline \multirow[t]{2}{*}{ Model: } & 1 & & 2 & & 3 & & 4 & \\
\hline & $\beta$ & t-stat & $\beta$ & t-stat & $\beta$ & t-stat & $\beta$ & t-stat \\
\hline $\mathrm{R} \& \mathrm{D}_{(\mathrm{t}-1)} / \operatorname{Assets}_{(\mathrm{t}-1)}$ & 0.502 & $12.61 * * *$ & 0.956 & $13.43 * * *$ & 1.226 & $4.82 * * *$ & 1.143 & $13.23^{* * *}$ \\
\hline$\left[\left(\mathrm{R}_{0} \mathrm{D}_{(\mathrm{t}-1)} / \operatorname{Assets}_{(\mathrm{t}-1)}\right]^{2}\right.$ & -0.032 & $-6.57 * * *$ & -2.312 & $-8.39 * * *$ & -1.263 & -1.58 & -0.883 & $-3.28 * * *$ \\
\hline $\operatorname{Sales}_{(t)} / \operatorname{Assets}_{(t)}$ & 0.017 & $2.57 * * *$ & 0.006 & $3.27 * * *$ & 0.010 & 0.75 & 0.024 & $3.16^{* * *}$ \\
\hline $\operatorname{Sales}_{(t-1)} / \operatorname{Assets}_{(t-1)}$ & -0.022 & $-3.48^{* * *}$ & -0.005 & $-3.12 * * *$ & -0.006 & -0.42 & -0.027 & $-3.4 * * *$ \\
\hline Cash Flow/(t) Assets $_{(\mathrm{t})}$ & 0.000 & -0.44 & -0.003 & -0.45 & 0.017 & 1.61 & -0.046 & $-2.4 * *$ \\
\hline Cash Flow $_{(\mathrm{t}-1)} /$ Assets $_{(\mathrm{t}-1)}$ & 0.000 & -1.44 & 0.003 & 0.42 & -0.021 & $-1.85^{*}$ & 0.020 & 1.11 \\
\hline Net Stock Issuance $_{(t)} /$ Assets $_{(t)}$ & 0.139 & $3.15^{* * *}$ & -0.012 & $-2.11 * *$ & -0.038 & -1.02 & -0.051 & -1.52 \\
\hline Net Stock Issuance $_{(\mathrm{t}-1)} / \operatorname{Assets}_{(\mathrm{t}-1)}$ & -0.013 & -0.83 & 0.005 & 1.06 & 0.079 & $1.96^{*}$ & 0.021 & 1.15 \\
\hline$\% \Delta \operatorname{RGDP}_{(\mathrm{t}-2)}$ & 0.001 & $4.19^{* * *}$ & 0.000 & 1.32 & 0.006 & 0.95 & 0.002 & $2.35^{* *}$ \\
\hline $\mathrm{KL}_{(\mathrm{t}-1)}$ & 0.000 & $-2.31 * *$ & -0.003 & -1.44 & -0.007 & -1.17 & -0.001 & -0.56 \\
\hline \multicolumn{9}{|l|}{ Country: } \\
\hline China & -0.032 & $-9.15 * * *$ & & & & & & \\
\hline France & 0.001 & 0.29 & & & & & & \\
\hline Germany & -0.001 & -0.41 & & & & & & \\
\hline Great Britain & 0.000 & 0.03 & & & & & & \\
\hline India & -0.026 & $-9.8^{* * *}$ & & & & & & \\
\hline Japan & -0.008 & $-6.61 * * *$ & & & & & & \\
\hline \multicolumn{9}{|l|}{ Industry: } \\
\hline Basic Materials & 0.008 & 1.59 & 0.001 & 0.27 & -0.006 & -0.66 & -0.004 & -1.04 \\
\hline Consumer - Cylical & 0.008 & 1.57 & 0.003 & 1.30 & -0.012 & -1.26 & -0.003 & -0.80 \\
\hline Consumer - Noncyclical & 0.006 & 1.08 & 0.001 & 0.24 & -0.010 & -1.19 & -0.003 & -0.78 \\
\hline Energy & -0.005 & -1.07 & 0.000 & 0.03 & -0.008 & -0.95 & 0.000 & 0.00 \\
\hline Healthcare & 0.041 & $7.24 * * *$ & 0.002 & 0.63 & 0.003 & 0.20 & 0.003 & 0.65 \\
\hline Industrial & 0.008 & 1.58 & 0.001 & 0.36 & -0.008 & -0.94 & -0.005 & -1.23 \\
\hline Independent & 0.005 & 0.89 & 0.003 & 1.09 & -0.010 & -1.30 & 0.000 & 0.00 \\
\hline Technology & 0.037 & $6.26^{* * *}$ & 0.006 & 2.00 & -0.014 & -0.91 & -0.005 & -1.02 \\
\hline Telecommunications & -0.005 & -0.92 & 0.000 & 0.18 & -0.005 & -0.72 & -0.002 & -0.41 \\
\hline $\mathrm{m} 1$ (p-value) & & 0.000 & & 0.001 & & 0.021 & & 0.001 \\
\hline m2 (p-value) & & 0.050 & & 0.263 & & 0.920 & & 0.103 \\
\hline Hansen (p-value) & & 0.000 & & 0.831 & & 0.925 & & 0.205 \\
\hline Firm-Years & & 31,943 & & 582 & & 661 & & 1,002 \\
\hline Firms & & 5,422 & & 165 & & 151 & & 197 \\
\hline
\end{tabular}

Continued

\begin{tabular}{|c|c|c|c|c|c|c|c|c|}
\hline & \multicolumn{2}{|c|}{ Great Britain } & \multicolumn{2}{|l|}{ India } & \multicolumn{2}{|l|}{ Japan } & \multicolumn{2}{|l|}{ US } \\
\hline \multicolumn{9}{|c|}{ Dependent Variable: $\quad R \& D_{(i t)} / \operatorname{Assets}_{(i t)}$} \\
\hline \multirow[t]{2}{*}{ Model: } & 5 & & 6 & & 7 & & 8 & \\
\hline & $\beta$ & t-stat & $\beta$ & t-stat & $\beta$ & t-stat & $\beta$ & t-stat \\
\hline$R \& D_{(t-1)} / \operatorname{Assets}_{(t-1)}$ & 0.516 & $6.23 * * *$ & 1.013 & $16.86^{* * *}$ & 1.037 & $26.16^{* * *}$ & 0.517 & $12.5^{* * *}$ \\
\hline$\left[\left(\mathrm{R}^{\prime} \mathrm{D}_{(\mathrm{t}-1)} / \operatorname{Assets}_{(\mathrm{t}-1)}\right]^{2}\right.$ & -0.028 & $-6.36^{* * *}$ & -2.912 & $-4.85^{* * *}$ & -0.745 & $-2.25 * *$ & -0.040 & $-7.73 * * *$ \\
\hline $\operatorname{Sales}_{(\mathrm{t})} / \operatorname{Assets}_{(\mathrm{t})}$ & 0.047 & $4.25 * * *$ & 0.002 & 1.32 & 0.006 & $4.86^{* * *}$ & 0.014 & $2.14^{* *}$ \\
\hline $\operatorname{Sales}_{(\mathrm{t}-1)} / \operatorname{Assets}_{(\mathrm{t}-1)}$ & -0.046 & $-4.93 * * *$ & -0.002 & -1.28 & -0.007 & $-5.21 * * *$ & -0.019 & $-2.96 * * *$ \\
\hline Cash Flow/(t) Assets ${ }_{(\mathrm{t})}$ & -0.002 & $-3.25 * * *$ & 0.001 & 0.98 & -0.001 & -0.34 & 0.000 & -0.17 \\
\hline $\operatorname{Cash} \operatorname{Flow}_{(t-1)} / \operatorname{Assets}_{(t-1)}$ & 0.000 & -0.94 & 0.000 & -0.50 & 0.006 & $2.82 * * *$ & 0.000 & -1.44 \\
\hline Net Stock Issuance $_{(t)} /$ Assets $_{(t)}$ & -0.062 & $-2.56^{* * *}$ & -0.002 & -0.49 & -0.043 & $-3.74 * * *$ & 0.170 & $3.66^{* * *}$ \\
\hline Net Stock Issuance $_{(t-1)} /$ Assets $_{(t-1)}$ & 0.051 & $3.01 * * *$ & 0.000 & -0.05 & 0.032 & 1.61 & -0.013 & -0.83 \\
\hline$\% \Delta \operatorname{RGDP}_{(\mathrm{t}-2)}$ & 0.019 & $2.82 * *$ & 0.000 & 0.47 & 0.001 & 1.59 & 0.005 & $1.92 *$ \\
\hline $\mathrm{KL}_{(\mathrm{t}-1)}$ & -0.006 & $-1.62 *$ & 0.000 & -0.67 & 0.000 & -1.51 & 0.000 & $-2.37 * *$ \\
\hline
\end{tabular}




\begin{tabular}{|c|c|c|c|c|c|c|c|c|}
\hline \multicolumn{9}{|l|}{ France } \\
\hline \multicolumn{9}{|l|}{ Germany } \\
\hline \multicolumn{9}{|l|}{ Great Britain } \\
\hline \multicolumn{9}{|l|}{ India } \\
\hline \multicolumn{9}{|l|}{ Japan } \\
\hline \multicolumn{9}{|l|}{ Industry: } \\
\hline Basic Materials & -0.026 & $-2.57 * * *$ & 0.000 & 0.19 & -0.001 & -1.31 & 0.01 & 1.56 \\
\hline Consumer - Cylical & 0.001 & 0.06 & 0.000 & -0.34 & 0.000 & -0.84 & 0.01 & 1.53 \\
\hline Consumer - Noncyclical & -0.028 & $-2.8 * * *$ & 0.000 & -0.04 & 0.000 & -0.76 & 0.01 & 1.35 \\
\hline Energy & -0.021 & $-2.14 * * *$ & 0.000 & -0.36 & 0.000 & 0.15 & 0.00 & -0.04 \\
\hline Healthcare & 0.021 & 1.58 & 0.002 & $2.84 * * *$ & 0.002 & $2.48 * * *$ & 0.05 & $6.51 * * *$ \\
\hline Industrial & -0.018 & $-1.9 *$ & 0.000 & 0.16 & -0.001 & -0.91 & 0.02 & $1.95^{*}$ \\
\hline Independent & 0.000 & 0 & 0.000 & -0.65 & 0.000 & -0.74 & 0.00 & 0.52 \\
\hline Technology & 0.023 & $2.09 * *$ & 0.000 & 0.41 & 0.000 & 0.24 & 0.05 & $5.95 * * *$ \\
\hline Telecommunications & -0.038 & $-2.2 * *$ & 0.010 & $7.81 * * *$ & -0.001 & -1.32 & 0.00 & 0.50 \\
\hline m1 (p-value) & & 0.002 & & 0.024 & & 0.000 & & 0.000 \\
\hline m2 (p-value) & & 0.267 & & 0.778 & & 0.452 & & 0.228 \\
\hline Hansen (p-value) & & 0.000 & & 0.080 & & 0.000 & & 0.000 \\
\hline Firm-Years & & 2,286 & & 1,024 & & 8,332 & & 18,056 \\
\hline Firms & & 412 & & 404 & & 1,208 & & 2,885 \\
\hline
\end{tabular}

Note. Estimates are produced by the Arellano-Bond one-step difference Generalized Method of Moments (GMM) with robust standard errors. All instruments include up to 2-year lags. Hansen (p-value) of overidentifying restrictions; $\operatorname{Pr}>|\mathrm{m} 1|$ and $\operatorname{Pr}>|\mathrm{m} 2|$ are the Arellano-Bond tests of first and second order residual serial correlation.

* Significant at $<0.10$ level. ** Significant at $<0.05$ level. *** Significant at $<0.01$ level.

\subsubsection{By Country-Technology Sector}

Table 5 presents the full-sample and by country econometric estimates of equation (6) for technology companies. Model 1 displays the all-country estimates where the lagged and lagged-squared dependent variables conform to prior expectations and are statistically significant. The coefficients on contemporaneous sales and net stock issuance variables are significant and confirm the importance of firm-level demand and equity funding to R\&D expenditures. On the other hand, the negligible size of the cash flow variable suggests that, in the aggregate, firms do not face meaningful financial constraints. The positive coefficient on the lagged GDP growth rate supports the pro-cyclical hypothesis of R\&D investment. Unfortunately, the negative association between $R \& D$ and the capital-labor ratio is contrary to expectations for the technology sector. The significant country dummy variables in model 1 imply that technology firms in France and Germany had above, and China and Japan had below-average R\&D expenditures relative to US technology firms.

Models 2 through 8 provide the econometric results for technology companies located in specific countries. The only consistently significant variables across all countries were the lagged dependent variables which underscore the importance of both expectations and quadratic adjustment costs to R\&D investments. US technology firms constitute the largest share of firm year observations and also had the most significant number of coefficients (see model 8). Furthermore, the significant contemporaneous sales and cash flow variables for US firms confirm the importance of demand and internal finance which support findings in BF\&P. The positive coefficient on lagged GDP growth implies that R\&D expenditures for US technology firms vary with the business cycle. The significant and relatively large negative coefficient on the capital labor ratio was contrary to expectations. Consistently negative coefficients on lagged sales and net stock issuance were also reported by BF\&P for both mature and young US technology firms ( $\mathrm{p}$. 170).

Japanese tech companies constitute the second largest share of observations with about $16 \%$ of the total sample. The significant positive value on the contemporaneous sales coefficient supports the hypothesis that firm demand is an important source of funding for Japanese technology firms. While current cash flow is not statistically significant, the lagged coefficient implies a significant longer-term impact on R\&D expenditures. In contrast, the negative coefficient on current net stock issuance is contrary to expectations and suggests that equity finance does not make a positive contribution to R\&D funding. The positive and significant coefficient on GDP growth supports a procyclical association with R\&D expenditures.

The only systematically significant estimates for French, German, and British firms were the coefficients on the 
lagged dependent variables; models 3 through 5 display the results for these countries. The coefficients on both lagged dependent variables for French and German firms are closer to the +1 and -1 expected values from the Euler investment model for "imperfectly competitive firms that accumulate productive assets with a quadratic adjustment cost technology (BF\&P, 2009, p. 161)." Contemporaneous sales also have a positive impact on R\&D expenditures for both French and British firms. Net stock issuance had a significantly negative impact for both German and British companies - a result opposite to expectations.

Table 5. Technology companies

\begin{tabular}{|c|c|c|c|c|c|c|c|c|}
\hline & \multicolumn{2}{|c|}{ All Countries } & \multicolumn{2}{|l|}{ China } & \multicolumn{2}{|l|}{ France } & \multicolumn{2}{|c|}{ Germany } \\
\hline \multicolumn{9}{|c|}{ Dependent Variable: $R \& D_{(i t)} / A_{s s e t s}(i t)$} \\
\hline \multirow[t]{2}{*}{ Model: } & 1 & & 2 & & 3 & & 4 & \\
\hline & $\beta$ & t-stat & $\beta$ & t-stat & $\beta$ & t-stat & $\beta$ & t-stat \\
\hline$R \& D_{(t-1)} / \operatorname{Assets}_{(t-1)}$ & 0.567 & $10.82 * * *$ & 1.037 & $4.93 * * *$ & 1.121 & $6.74 * * *$ & 1.290 & $8.2 * * *$ \\
\hline$\left[\left(\mathrm{R} \& \mathrm{D}_{(\mathrm{t}-1)} / \operatorname{Assets}_{(\mathrm{t}-1)}\right]^{2}\right.$ & -0.037 & $-9.25 * * *$ & -1.972 & -1.02 & -1.499 & $-2.58 * *$ & -1.663 & $-2.42 * *$ \\
\hline $\operatorname{Sales}_{(\mathrm{t})} / \operatorname{Assets}_{(\mathrm{t})}$ & 0.040 & $3 * * *$ & 0.013 & $2.13 * *$ & 0.066 & $2.8^{* * *}$ & 0.019 & 1.53 \\
\hline $\operatorname{Sales}_{(\mathrm{t}-1)} / \operatorname{Assets}_{(\mathrm{t}-1)}$ & -0.043 & $-3.2 * * *$ & -0.017 & $-2.64 * *$ & -0.058 & $-2.6^{* *}$ & -0.020 & -1.56 \\
\hline Cash Flow/(t) Assets $_{(\mathrm{t})}$ & 0.000 & $2.43 * *$ & -0.008 & -0.62 & 0.031 & 1.14 & -0.053 & $-2.38 * *$ \\
\hline Cash Flow $_{(\mathrm{t}-1)} / \operatorname{Assets}_{(\mathrm{t}-1)}$ & 0.000 & -0.88 & 0.028 & $1.72 *$ & 0.001 & 0.05 & 0.019 & 1.11 \\
\hline Net Stock Issuance $(t) /$ Assets $_{(t)}$ & 0.131 & $3.36^{* * *}$ & -0.005 & -0.37 & 0.072 & 1.03 & -0.122 & $-2.82 * * *$ \\
\hline Net Stock Issuance $(\mathrm{t}-1) / \operatorname{Assets}_{(\mathrm{t}-1)}$ & -0.058 & $-2.43 * * *$ & -0.005 & -0.42 & 0.020 & 0.69 & 0.026 & 1.40 \\
\hline$\% \Delta \operatorname{RGDP}_{(\mathrm{t}-2)}$ & 0.002 & $2.82 * * *$ & 0.001 & $1.81^{*}$ & 0.002 & 0.23 & 0.001 & 0.27 \\
\hline $\mathrm{KL}_{(\mathrm{t}-1)}$ & -0.019 & $-3.8 * * *$ & -0.010 & -0.99 & -0.013 & -0.83 & 0.001 & 0.03 \\
\hline \multicolumn{9}{|l|}{ Country: } \\
\hline China & -0.050 & $-7.05 * * *$ & & & & & & \\
\hline France & -0.006 & -1.16 & & & & & & \\
\hline Germany & -0.013 & $-2.88 * * *$ & & & & & & \\
\hline Great Britain & 0.000 & -0.04 & & & & & & \\
\hline India & -0.058 & $-8.67 * * *$ & & & & & & \\
\hline Japan & -0.027 & $-6.18 * * *$ & & & & & & \\
\hline m1 (p-value) & & 0.000 & & 0.020 & & 0.053 & & 0.011 \\
\hline $\mathrm{m} 2$ (p-value) & & 0.133 & & 0.393 & & 0.384 & & 0.712 \\
\hline Hansen (p-value) & & 0.000 & & 0.154 & & 1.000 & & 1.000 \\
\hline Firm-Years & & 7,709 & & 115 & & 192 & & 316 \\
\hline Firms & & 1,181 & & 30 & & 45 & & 56 \\
\hline
\end{tabular}

Continued

\begin{tabular}{|c|c|c|c|c|c|c|c|c|}
\hline & \multicolumn{2}{|c|}{ Great Britain } & \multicolumn{2}{|l|}{ India } & \multicolumn{2}{|l|}{ Japan } & \multicolumn{2}{|l|}{ US } \\
\hline \multicolumn{9}{|c|}{ Dependent Variable: $R \& D_{(i t)} /$ Assets $_{(i t)}$} \\
\hline \multirow[t]{2}{*}{ Model: } & 5 & & 6 & & 7 & & 8 & \\
\hline & $\beta$ & t-stat & $\beta$ & t-stat & $\beta$ & t-stat & $\beta$ & t-stat \\
\hline$R \& D_{(t-1)} / \operatorname{Assets}_{(t-1)}$ & 0.826 & $8.25 * * *$ & 0.729 & $3.73^{* * *}$ & 1.130 & $17.49^{* * *}$ & 0.593 & $11.75^{* * *}$ \\
\hline$\left[\left(\mathrm{R} \& \mathrm{D}_{(\mathrm{t}-1)} / \operatorname{Assets}_{(\mathrm{t}-1)}\right]^{2}\right.$ & -0.258 & $-8.25 * * *$ & -0.709 & -0.53 & -1.767 & $-2.62 * * *$ & -0.038 & $-9.56 * * *$ \\
\hline Sales $_{(t)} / \operatorname{Assets}_{(t)}$ & 0.076 & $4.6^{* * *}$ & 0.007 & 1.30 & 0.007 & $2.72 * * *$ & 0.037 & $2.43 * * *$ \\
\hline $\operatorname{Sales}_{(t-1)} / \operatorname{Assets}_{(t-1)}$ & -0.067 & $-4.43 * * *$ & -0.008 & -1.22 & -0.008 & $-2.96 * * *$ & -0.040 & $-2.59 * * *$ \\
\hline Cash Flow/(t) Assets $_{(\mathrm{t})}$ & -0.006 & -1.43 & -0.002 & -0.42 & -0.004 & -1.14 & 0.000 & $3.14 * * *$ \\
\hline Cash Flow $_{(t-1)} /$ Assets $_{(t-1)}$ & 0.001 & 0.61 & 0.004 & 1.09 & 0.008 & $6.59 * * *$ & 0.000 & $-1.8^{*}$ \\
\hline Net Stock Issuance $_{(t)} /$ Assets $_{(t)}$ & -0.059 & $-1.99 *$ & 0.007 & 1.19 & -0.029 & $-2.39 * *$ & 0.156 & $4.17 * * *$ \\
\hline Net Stock Issuance ${ }_{(t-1)} /$ Assets $_{(t-1)}$ & 0.020 & 1.00 & -0.008 & $-1.91 *$ & 0.010 & 0.99 & -0.079 & $-3.48 * * *$ \\
\hline$\% \Delta \operatorname{RGDP}_{(t-2)}$ & 0.010 & 1.10 & 0.000 & 1.50 & 0.002 & $2.01 * *$ & 0.017 & $8.31 * * *$ \\
\hline $\mathrm{KL}_{(\mathrm{t}-1)}$ & -0.070 & $-2.27 * *$ & -0.002 & -0.46 & -0.002 & -0.62 & -0.022 & $-3.74 * * *$ \\
\hline \multicolumn{9}{|l|}{ Country: } \\
\hline \multicolumn{9}{|l|}{ China } \\
\hline \multicolumn{9}{|l|}{ France } \\
\hline Germany & & & & & & & & \\
\hline
\end{tabular}




\begin{tabular}{|c|c|c|c|c|}
\hline \multicolumn{5}{|l|}{$\begin{array}{l}\text { Great Britain } \\
\text { India } \\
\text { Japan } \\
\end{array}$} \\
\hline m1 (p-value) & 0.004 & 0.136 & 0.000 & 0.000 \\
\hline m2 (p-value) & 0.702 & 0.107 & 0.977 & 0.210 \\
\hline Hansen (p-value) & 1.000 & 1.000 & 0.248 & 0.000 \\
\hline Firm-Years & 609 & 92 & 1,322 & 5,063 \\
\hline Firms & 105 & 36 & 200 & 709 \\
\hline
\end{tabular}

Note. Estimates are produced by the Arellano-Bond one-step difference Generalized Method of Moments (GMM) with robust standard errors. All instruments include up to 2-year lags. Hansen (p-value) of overidentifying restrictions; $\operatorname{Pr}>|\mathrm{m} 1|$ and $\operatorname{Pr}>|\mathrm{m} 2|$ are the Arellano-Bond tests of first and second order residual serial correlation.

* Significant at $<0.10$ level. ${ }^{* *}$ Significant at $<0.05$ level. *** Significant at $<0.01$ level.

\section{Conclusions}

The mixed results regarding the determinants of R\&D expenditures across countries and sectors are not unexpected. Indeed, Bond et al. (2003) found uneven support for their hypotheses about capital investment and financial constraints for a panel of European companies from 1978-1989. While there were significant differences between the aggregate and individual country results, the diversity of outcomes yielded some noteworthy findings.

First, net shareholder-supplied finance is confirmed to be an important source of external funding for US technology firms. Comparisons with BF\&P's contemporaneous net stock issuance coefficients for mature and young US firms were similar in sign and magnitude to our estimates. Country dummy variables indicate that non-US technology firms have lower average R\&D expenditures per dollar of assets. Unfortunately, contemporaneous net stock issuance had either a negative or no impact on R\&D expenditures in the other countries examined in this investigation. Individual country models estimated across all sectors generated similar results, although lagged net stock issuance did have a positive impact in France, and Great Britain. Differences in financial and institutional relationships between capital market and bank-based systems of corporate finance may explain part of these outcomes. For example, BF\&P observed that a country's "financial architecture" can be critical for funding new high tech firms that require significant levels of R\&D. Moreover, while US equity markets facilitated the funding of high tech R\&D expenditures, France and Germany's bank-based economies were much less successful in creating new ventures while their share of world high-tech production fell significantly from 1990 through 2004 (ibid, p. 180). Secondly, an autoregressive specification of R\&D expenses with quadratic adjustment costs is generally robust across countries and sectors. Although expected point estimates for the lagged and lagged squared regressors of +1 and -1 were not obtained, nearly every model produced the expected sign and was consistently significant. Mixed support was obtained for the financial constraint hypothesis: while US technology companies appear to be financial constrained, however, the effect was rather small. Contemporaneous sales, though not always statistically significant, proved to be a useful proxy for firm output and demand. Thus, an Euler investment function has utility to modeling both international and sector-specific R\&D expenses.

The third result concerns the observed negative correlation between capital intensity and $R \& D$ expenditures. Unfortunately, the consistently negative coefficient for the technology sector was inconsistent with prior expectations of a positive association between R\&D expenditures and capital intensity within this particularly knowledge-intensive sector. Alternatively, assuming the non-technology sectors (e.g., basic materials, energy, consumer noncyclical) produce a relatively homogeneous output (that rely less upon knowledge-intensive production methods and techniques), the negative correlation with R\&D expenditures is consistent with prior reasoning and empirical results in Audretsch et al. (1996). Thus, while R\&D investments may not play a significant role in capital intensive sectors, we could not find support for a positive impact of capital intensity within the US or international technology sector.

The fourth and final conclusion is that macroeconomic growth had a consistently positive impact on firm-level $R \& D$ expenditures across the countries and sectors examined in this study. A statistically significant relationship was observed for the aggregate country sample as well as in Germany, Great Britain, and the US. This finding also underscores the importance of including relevant macroeconomic factors in microeconometric panel models of firm-level outcomes such as R\&D expenditures. Within the technology sector, aggregate economic growth had a significant positive impact in China, Japan, and the US. Thus, support is found for the hypothesis that 
economic growth provides firms in these countries with additional sales and profits to fund R\&D activities.

\section{References}

Agion, P., \& Saint-Paul, G. (1998). Virtues of bad times: interaction between productivity growth and economic fluctuations. Macroeconomic Dynamics, 2(3), 322-344.

Akerlof, G. (1970). The market for 'lemons:' quality and uncertainty and the market mechanism. Quarterly Journal of Economics, 84, 488-500. http://dx.doi.org/10.2307/1879431

Arrelano, M., \& Bond, S. (1991). Some tests of specification for panel data: Monte Carlo evidence and an application to employment equations. Review of Economic Studies, 58, 277-297. http://dx.doi.org/10.2307/2297968

Arrow, K. (1962). Economic welfare and the allocation of resources for invention. In R. Nelson (Ed.), The Rate and Direction of Inventive Activity: Economic and Social Factors. Princeton University Press.

Audretsch, D. B., Menkveld, A. J., \& Thurik, A. R. (1996). The decision between internal and external R\&D. Journal of Institutional and Theoretical Economics, 152(3), 519-530.

Barlevy, G. (2007). On the cyclicality of research and development. American Economic Review, 97(4), 11311164. http://dx.doi.org/10.1257/aer.97.4.1131

Bond, S., \& Meghir, C. (1994). Dynamic investment models and the firm's financial policy. Review of Economic Studies, 61, 197-222. http://dx.doi.org/10.2307/2297978

Bond, S., Elston, J. A., Mairesse, J., \& Mulkay, B. (2003). Financial factors and investment in Belgium, France, Germany, and the United Kingdom: a comparison using company panel data. Review of Economics and Statistics, 85(1), 153-165. http://dx.doi.org/10.1162/003465303762687776

Brown, J., Fazzari, S., \& Petersen, B. (2009). Financing innovation and growth: cash flow, external equity, and the $1990 \mathrm{~s} \quad$ R\&D boom. Journal of Finance, 64(1), 151-185. http://dx.doi.org/10.1111/j.1540-6261.2008.01431.x

Carpenter, R., \& Petersen, B. (2002a). Capital market imperfections, high-tech investment, and new equity financing. Economic Journal, 112, 54-72. http://dx.doi.org/10.1111/1468-0297.00683

Carpenter, R., \& Petersen, B. (2002a). Is the growth of small firms constrained by internal finance? Review of Economics and Statistics, 84(2), 298-309. http://dx.doi.org/10.1162/003465302317411541

Comin, D., \& Gertler, M. (2006). Medium term business cycles. American Economic Review, 96(3), $523-551$.

Fazzari, S., Hubbard, R. G., \& Peterson, B. (1988). Financing constraints and corporate investment. Brookings Papers on Economic Activity, 19, 141-195. http://dx.doi.org/10.2307/2534426

Field, A. (2003). The most technologically progressive decade. American Economic Review, 93(4), $1399-1413$. http://dx.doi.org/10.1257/000282803769206377

Greeenwald, B., \& Stiglitz, J. (1993). Financial market imperfections and business cycles. Quarterly Journal of Economics, 108(1), 77-114. http://dx.doi.org/10.2307/2118496

Hall, B. (2002). The financing of research and development. UC Berkeley Working Papers, Department of Economics, E01-311.

Himmelberg, C., \& Petersen, B. (1994). R\&D and internal finance: a panel study of small firms in high-tech industries. Review of Economics and Statistics, 76(1), 38-51. http://dx.doi.org/10.2307/2109824

Hubbard, R. (1998). Capital market imperfections and investment. Journal of Economic Literature, 36(2), 193225.

Lamont, O. (1997). Cash flow and investment: evidence from internal capital markets. Journal of Finance, 52(1), 83-109. http://dx.doi.org/10.1111/j.1540-6261.1997.tb03809.x

Levin, R., Klevorick, A., Nelson, R., \& Winter, S. (1987). Appropriating the returns from industrial research and development. Brookings Papers on Economic Activity, 18(3), 783-831. http://dx.doi.org/10.2307/2534454

Mansfield, E., Schwartz, M., \& Wagner, S. (1981). Imitation costs and patents: an empirical study. Economic Journal, 91, 907-918. http://dx.doi.org/10.2307/2232499

Muller, E., \& Zimmerman, V. (2006). The importance of equity finance for R\&D activity-are there differences between young and old companies? Governance and the Efficiency of Economic Systems (GESY), Discussion paper no. 111. 
Nelson, R. (1959). The simple economics of basic scientific research. Journal of Political Economy, 67(3), 297306. http://dx.doi.org/10.1086/258177

OECD. (2012). Research and Development Statistics. Retrieved from http://www.oecd.org/

Ouyang, M. (2008). On the cyclicality of R\&D, Federal Reserve Bank of Atlanta. Retrieved from http://www.frbatlanta.org/filelegacydocs/seminars/seminar_ouyang_031609.pdf

Rafferty, N. (2003). Do business cycles influence long run growth? The effect of aggregate demand on firm-financed R\&D expenditures. Eastern Economic Journal, 29(4), 607-618.

Schiantarelli, F. (1995). Financial constraints and investments: a critical review of the methodological issues and international evidence. In J. Peek \& E. Rosengren (Eds.), Is Bank Lending Important for the Transmission of Monetary Policy (pp. 177-214). Boston: Federal Reserve Bank.

Schumpeter, J. (1950). Capitalism, Socialism, and Democracy. Harper Torchbooks.

Stiglitz, J., \& Weiss, A. (1981). Credit rationing in markets with imperfect information. American Economic Review, 17(3), 393-410.

Ughetto. (2008). Does finance matter for R\&D investment? New evidence from a panel of Italian firms. Cambridge Journal of Economics, 32(6), 907-925. http://dx.doi.org/10.1093/cje/ben015

Walde, K., \& Woitek, W. (2004). R\&D expenditures in G-7 countries and the implications for endogenous fluctuations and growth. Economic Letters, 82(1), 91-97. http://dx.doi.org/10.1016/j.econlet.2003.07.014

Windmeijer, F. (2005). A finite sample correction for the variance of linear efficient two-step GMM estimation. Journal of Econometrics, 126, 25-51. http://dx.doi.org/10.1016/j.jeconom.2004.02.005

Zhang, A., Zhang, Y., \& Zhao, R. (2003). A study of the R\&D efficiency and productivity of Chinese firms. Journal of Comparative Economics, 31, 444-464. http://dx.doi.org/10.1016/S0147-5967(03)00055-6

\section{Notes}

Note 1. From this table 3 one can conclude that the asset specificity argument applies to low-tech industries and not to high-tech industries. For low-tech industries a higher level of Capital Intensity and a lower level of Skilled Labor favor external R\&D and hamper internal R\&D (Audretsch et. al., 1996, p. 526).

Note 2. All variables are scaled by total assets because of the lack of a stock measure of a firm's R\&D resources. As BF\&P (2009) note: "Measurement of the R\&D stock, however, is fraught with difficulties. The absence of a long time series of R\&D expenditures makes perpetual inventory methods for stock computations infeasible and the depreciation rate for an intangible asset like R\&D hard to determine. We therefore use firm's stock of total assets as a scale factor in the regressions and assume that adjustment costs of R\&D are quadratic in the ratio of R\&D-to-total assets (p. 2009, 161)."

Note 3. BF\&P define their cashflow variable as the sum of net after-tax income, depreciation, and $R \& D$ expenses (BF\&P, p. 162).

Note 4. Bond and Meghir (1994) and Ughetto (2008) had the same pattern of a significant and insignificant $m 1$ and $m 2$ statistic, respectively, and indicated that serial correlation was not a problem.

\section{Copyrights}

Copyright for this article is retained by the author(s), with first publication rights granted to the journal.

This is an open-access article distributed under the terms and conditions of the Creative Commons Attribution license (http://creativecommons.org/licenses/by/3.0/). 